\title{
INTERESTING FINDINGS OF ORIBATID MITES (ACARI: ORIBATIDA) FROM A SPHAGNUM BOG IN WESTERN SIBERIA
}

\author{
Marina L. Egorova1, Satoshi Shimano ${ }^{2}$ and Badamdorj Bayartogtokh ${ }^{3^{*}}$
}

\author{
${ }^{1}$ Department of Invertebrate Zoology, Biological Institute, Tomsk State University, Tomsk, Russia \\ ${ }^{2}$ Science Research Center, Hosei University, Fujimi, Chiyoda-ku, Tokyo, Japan \\ ${ }^{3}$ Department of Biology, School of Arts and Sciences, National University of Mongolia, Ulaanbaatar, \\ Mongolia \\ *corresponding author; e-mail: bayartogtokh@num.edu.mn
}

\begin{abstract}
This work deals with six species of oribatid mites recovered from a sedge-moss bog (Carex-Eriophorum-Sphagnum association), located in the south of Western Siberia, Russia. Two species, Banksinoma exobothridialis and Banksinoma longisetosa (Thyrisomidae) are new to the fauna of Russia. This finding is interesting in regards to the biogeography and the habitat ecology of both species. Two other relatively rare species of Trhypochthoniidae have been found: Mainothrus badius, which is recorded for the first time in Asia; and Trhypochthonius nigricans, recorded for the first time in Western Siberia. In addition, Holarctic species Suctobelbella palustris (Suctobelbidae) and Limnozetes ciliatus (Limnozetidae) are reported with supplementary descriptions and illustrations. In this article, we discuss the distribution and habitat ecology of each of the above species.
\end{abstract}

KEY WORDS: Moss mites, new finding, Sphagnum bog, Tomsk Region.

DOI: 10.21684/0132-8077-2020-28-1-3-16

\section{INTRODUCTION}

Oribatid mites are primarily terrestrial and often dominate microarthropod diversity in litter and soil, where they feed mainly on plant tissue, fungi and algae (Norton and Behan-Pelletier 2009). They are also found in various aquatic habitats, such as phytotelmata, temporary and permanent pools, spring seepages and permanent meltwaters, large water bodies (i.e., streams, lakes and peatlands), brackish and marine sublittoral and littoral waters (Behan-Pelletier and Norton 2016). In particular, oribatid mites are the most abundant group of microarthropods in boreal bogs. However, although they are usually the most abundant and diverse group of invertebrates in bogs, where they play an important role as decomposers (Kuriki 2008; Seniczak 2011), oribatid mites from these habitats are poorly known.

Only about 90 oribatid mite species from 10 genera (less than $1 \%$ of all known species) are truly aquatic, with all stages of their life cycle, including reproduction, occurring in freshwater (Schatz and Behan-Pelletier 2008). However, many terrestrial oribatid species are occasionally found in aquatic habitats. This happens as they fall from trees, flushed by rain or floods (Weigmann and Deichsel 2006).

The West Siberian Lowland is the world's largest high-latitude wetland, containing over $900,000 \mathrm{~km}^{2}$ of peatlands. The peatlands of West Siberia are of major importance to high-latitude hydrology, carbon storage and environmental history. These habitats are a major pool of stored carbon and a significant com- ponent in planetary carbon sequestration and emission calculations. Palaeoenvironmental data on the impact of the past climatic change on the peatlands can help anticipate the effects of global warming (Kremenetski et al. 2003). In addition to providing important ecosystem services - such as biomass production, supply of food sources and nitrogen and carbon cycling-peatlands are also heterogeneous habitats, where plants and animals must cope with increasing levels of abiotic disturbance (Liss et al. 2001).

Despite their importance, relatively little is known about the diversity and ecology of oribatid mites of Siberian peatlands (see Tolstikov 1998; Mikheeva 2008; Tolstikov and Petrova-Nikitina 2008).

Although there are many publications on oribatid mites recovered from various peatlands in the Holarctic region, many of these works are fragmentary and incomplete, often limited to simply listing a few species at a time. Such incomplete data cause difficulties in terms of biogeographical or ecological analyses of the fauna (see Mumladze et al. 2013). Thus, detailed investigations, accompanied by supplementary descriptions and illustrations, are important for clarifying the status of doubtful peatland records.

The purpose of the present study is to contribute to our understanding of the diversity of oribatid mites in the sedge-Sphagnum bogs of Western Siberia. Our assessment of biodiversity, community composition, biogeography, and other basic parameters of regional soil biota will provide soil 


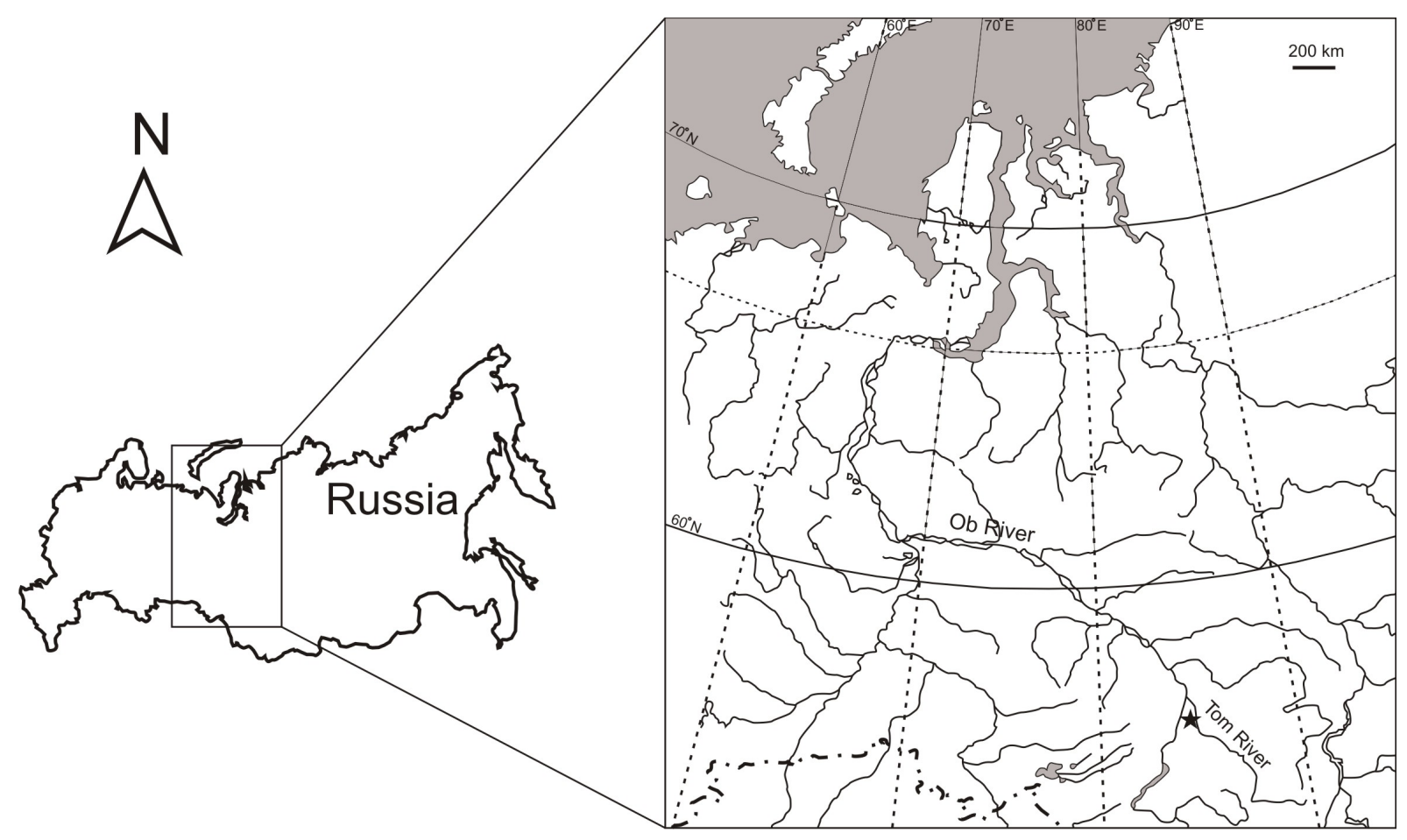

Fig. 1. Location of the sampled bog in the south of Western Siberia.

biologists a background from which to begin further, more detailed studies.

\section{MATERIALS AND METHODS}

The material was collected by the first author from a bog located about $10 \mathrm{~km}$ southwest of the city of Tomsk, Tomsk Region, Siberian Federal District, Russia $\left(56^{\circ} 26^{\prime} \mathrm{N}, 84^{\circ} 50^{\prime} \mathrm{E}\right)$. The study area is located on the interfluve plain of the $\mathrm{Ob}^{\prime}$ and Tom' Rivers, in the southern taiga forest zone (Fig. $1)$. Most of the area is occupied by forested peatlands, which support small scattered trees, such as larch, pine and birch. Floodplains of the $\mathrm{Ob}^{\prime}$ and Tom' Rivers are covered mainly by sedge and grass meadows (Kremenetski et al. 2003). The inspected bog is dominated by oligotrophic vascular plants (Carex rostrata, Eriophorum vaginatum) and Sphagnum mosses. In slightly elevated places, the moss cover is composed mainly of Sphagnum magellanicum, whereas in the lower lying areas, Sphagnum fallax and Sphagnum papillosum dominate. Occasional low pines (Pinus sylvestris, height of 1-2 m) and shrubs (Andromeda polifolia, Chamaedaphne calyculata) are also present. The average water level in the bog is maintained at the depth of $10-15 \mathrm{~cm}$ below the top of the mosses during the growing season.

Samples were taken from the sedge-Sphagnum bog and from the area located at the border between trees, shrubs and the bog. Soil mites were extracted with the help of modified Berlese-Tullgren's funnels over the course of 5-7 days in the laboratory. Specimens were cleared in lactic acid and mounted in lactic acid on temporary cavity slides for measurement and illustration. A differential interference contrast microscope was used for examining the morphology of specimens in transmitted light. Line drawings were made using a camera lucida, attached to the compound microscope.

Body lengths were measured in lateral view, from the tip of the rostrum to the posterior edge of the ventral plate. Notogastral width refers to the maximum width of the notogaster. Lengths of body setae were measured in lateral aspect.

The morphological terminology used in this paper follows that of Grandjean $(1932,1964)$ and Norton (1977) for leg setal nomenclature, and that of Norton and Behan-Pelletier (2009) for overview.

\section{RESULTS}

This work deals with six species of oribatid mites: three are recorded in Russia for the first time, one is recorded for the first time in Asia, and two others are rather common species in the Holarctic region. Since these species are easily recognizable, we do not provide their detailed redescriptions, but rather just short diagnostic characterizations, accompanied by illustrations. Following the supplementary descrip- 
tions, we discuss some aspects of the distribution and the habitat ecology for each species.

Family Trhypochthoniidae Willmann, 1931 Genus Mainothrus Choi, 1996

Type species: Mainothrus aquaticus Choi, 1996

\section{Mainothrus badius (Berlese, 1905)}

(Fig. 2)

Measurements. Adult body length: $579 \mu \mathrm{m}$, width of notogaster: $317 \mu \mathrm{m}$, length of notogaster: $406 \mu \mathrm{m}$. Deutonymph body length: $368-378 \mu \mathrm{m}$, width of gastronotum: 173-210 $\mu \mathrm{m}$, length of gastronotum: $237-256 \mu \mathrm{m}$. Tritonymph body length: $422 \mu \mathrm{m}$, width of gastronotum: $221 \mu \mathrm{m}$, length of gastronotum: $288 \mu \mathrm{m}$.

Supplementary description. Body colour deep reddish brown. Integument finely porose, with very faint reticulate ornamentation on notogaster. Rostrum broadly rounded, rostral seta (ro) $42 \mu \mathrm{m}$ in length, inserted dorsally on rostrum; lamellar seta (le) $44 \mu \mathrm{m}$ long; distance between le-le subequal to that of ro-ro; interlamellar seta (in) $64 \mu \mathrm{m}$, all these prodorsal setae minutely barbed (Fig. 2A, D). Sensillus (ss) $58 \mu \mathrm{m}$ long, lanceolate, with few serrations; exobothridial seta not evident, probably vestigial (Fig. 2C). Anterior margin of notogaster slightly concave, posterior margin rounded. Fifteen pairs of notogastral setae setiform, smooth; additionally $f_{1}$ represented by alveolus, inserted anteromedially to $h_{1}$ (Fig. 2B, E). Setae $c_{1}, c_{2}, c_{3}, d_{1}, d_{2}$ 6-11 $\mu \mathrm{m}, p_{2}$ and $e_{2} 32-34 \mu \mathrm{m}, e_{1}, f_{2}$ and $p_{3} 16-$ $18 \mu \mathrm{m}, h_{1} 54 \mu \mathrm{m}, h_{2} 70 \mu \mathrm{m}, h_{3} 20 \mu \mathrm{m}, p_{1} 76 \mu \mathrm{m}$ in length. Subcapitular setae setiform, smooth; seta $a$ $18 \mu \mathrm{m}, m$ and $h 6-8 \mu \mathrm{m}$ in length. Epimeral setae thin, smooth, 10-18 $\mu \mathrm{m}$ long; setal formula: $3-1-3-2$, seta $4 a$ absent. Anterior end of genital plate slightly protruded and markedly sclerotized; five pairs of genital setae 4-6 $\mu \mathrm{m}$ long, thin, smooth; anal opening narrow, two pairs of anal and three pairs of adanal setae 8-12 $\mu \mathrm{m}$ long, thin, smooth; lyrifissures ian and iad well developed (Fig. 2B); legs tridactylous.

Material examined. Eleven adults, one tritonymph and four deutonymphs: Sedge-Sphagnum bog near the Timiryazyevskoe village, $10 \mathrm{~km}$ southwest of the city of Tomsk, Tomsk Region, Russia $\left(56^{\circ} 26^{\prime} 30^{\prime \prime} \mathrm{N}, 84^{\circ} 50^{\prime} 06^{\prime \prime} \mathrm{E}\right), 1$ October 2015 , Leg. M.L. Egorova.

Remarks. The characters of the present material correspond well with those of the European and North American materials studied by Mahunka and
Mahunka-Papp (1995), Weigmann (1997), Seniczak et al. (1998), Ermilov and Chistyakov (2007). In particular, Seniczak et al. (1998) studied the morphology of the juvenile stages of this species based on North American materials.

\section{Trhypochthonius nigricans Willmann, 1928}

(Fig. 3)

Measurements. Adult body length: $496 \mu \mathrm{m}$, width of notogaster: $304 \mu \mathrm{m}$, length of notogaster: $352 \mu \mathrm{m}$.

Supplementary description. Body colour deep reddish brown. Integument porose, with very faint reticulate ornamentation on notogaster. Rostrum rounded, rostral seta $60 \mu \mathrm{m}$ long, barbed, pointed distally; lamellar setae $32 \mu \mathrm{m}$, barbed, blunt at tip; distance between le-le slightly greater than that of ro-ro; interlamellar setae $42 \mu \mathrm{m}$ long, barbed, thicker than rostral and lamellar setae. Sensillus $34 \mu \mathrm{m}$ long, its head rounded with distinct spines in apical part; exobothridial seta not evident, probably vestigial (Fig. 2A, C, D). Anterior margin of notogaster nearly straight, posterior margin rounded. Fifteen pairs of notogastral setae well developed, additionally $f_{1}$ represented by alveolus; seta $p_{2}$ setiform, pointed distally, $28 \mu \mathrm{m}$ long; $h_{3}$ and $p_{3}$ very short, but thick, smooth, 10-11 $\mu \mathrm{m}$ long; other notogastral setae barbed, blunt at the tip. Setae $c_{1}, c_{2}, c_{3}, c p, d_{1}, d_{2}$, $e_{1} 16-22 \mu \mathrm{m}, e_{2}, f_{2}, h_{1}, h_{2}$ and $p_{1} 28-34 \mu \mathrm{m}$ in length. Subcapitular setae setiform, smooth; seta $a 14 \mu \mathrm{m}, m$ and $h 10-12 \mu \mathrm{m}$ in length. Epimeral setae thin, smooth, 10-16 $\mu \mathrm{m}$ long; setal formula: $3-1-3-3$. Anal and genital shields similar in length; eight pairs of genital setae 15-20 $\mu \mathrm{m}$ long, thin, smooth; one pair of anal and three pairs of adanal setae thick, smooth, 10-12 $\mu \mathrm{m}$ long; lyrifissures ian and iad well developed (Fig. 3B); legs tridactylous.

Material examined. Twelve specimens: a bog near the Timiryazyevskoe village, $10 \mathrm{~km}$ southwest of the city of Tomsk, Tomsk Region, Russia (56 $\left.26^{\prime} 23^{\prime \prime} \mathrm{N}, 84^{\circ} 50^{\prime} 04^{\prime \prime} \mathrm{E}\right), 1$ October 2015, Leg. M.L. Egorova.

Remarks. The characters of the present material correspond well with those of the European and Asian materials studied by Aoki (1995), Weigmann (1997), Szywilewska-Szczykutowicz and Olszanowski (2007). In addition, Seniczak and Norton (1994) studied the morphology of the juvenile stages of this species based on North American materials. 
M.L. Egorova et al.

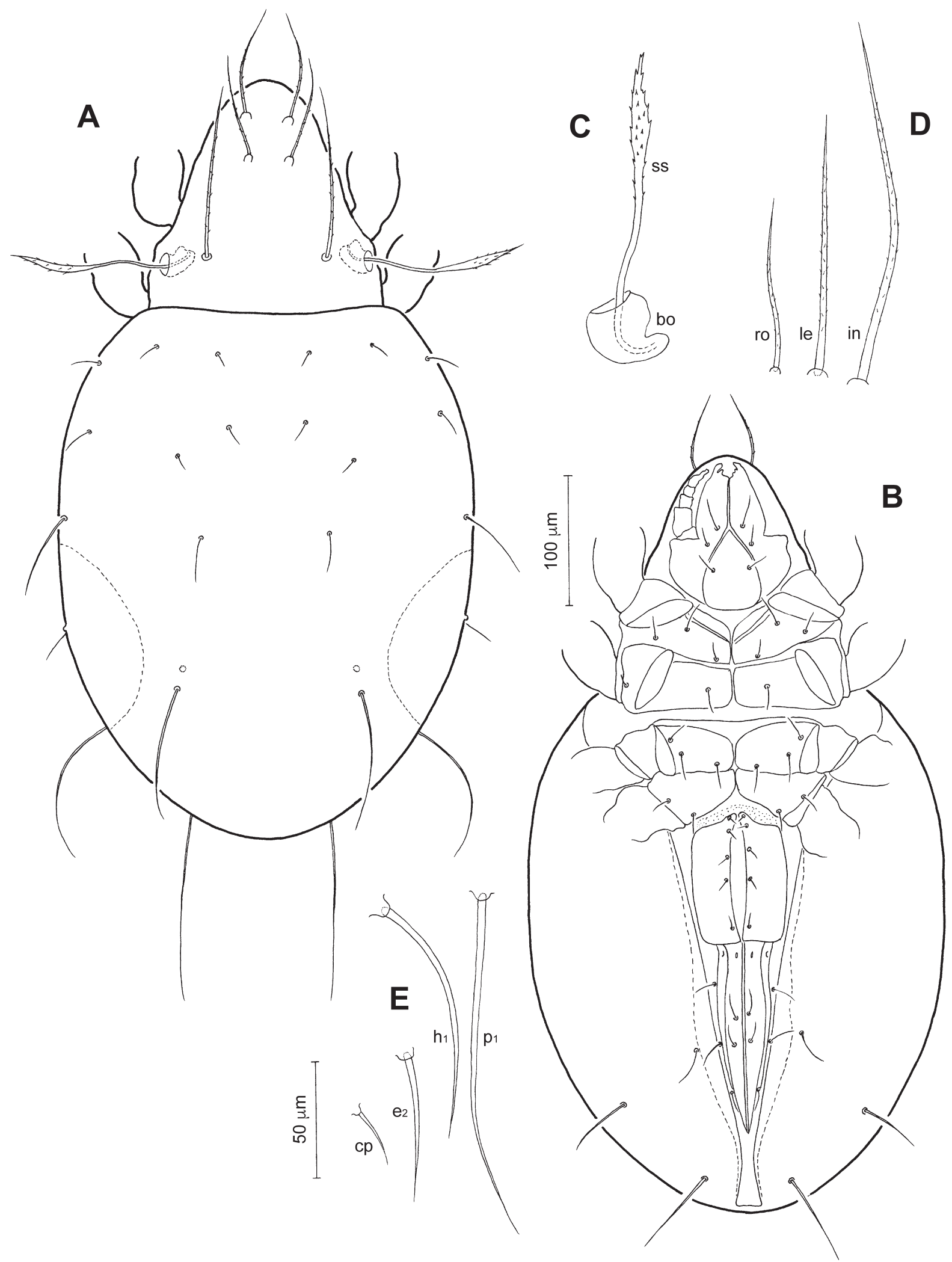

Fig. 2. Mainothrus badius (Berlese, 1905). A -dorsal view; B - ventral view; C-bothridium and sensillus; D-rostral, lamellar and interlamellar setae; E-notogastral setae $c p, e_{2}, h_{1}$ and $p_{1}$. A, B and C, D, E to the same scale, respectively.

6 


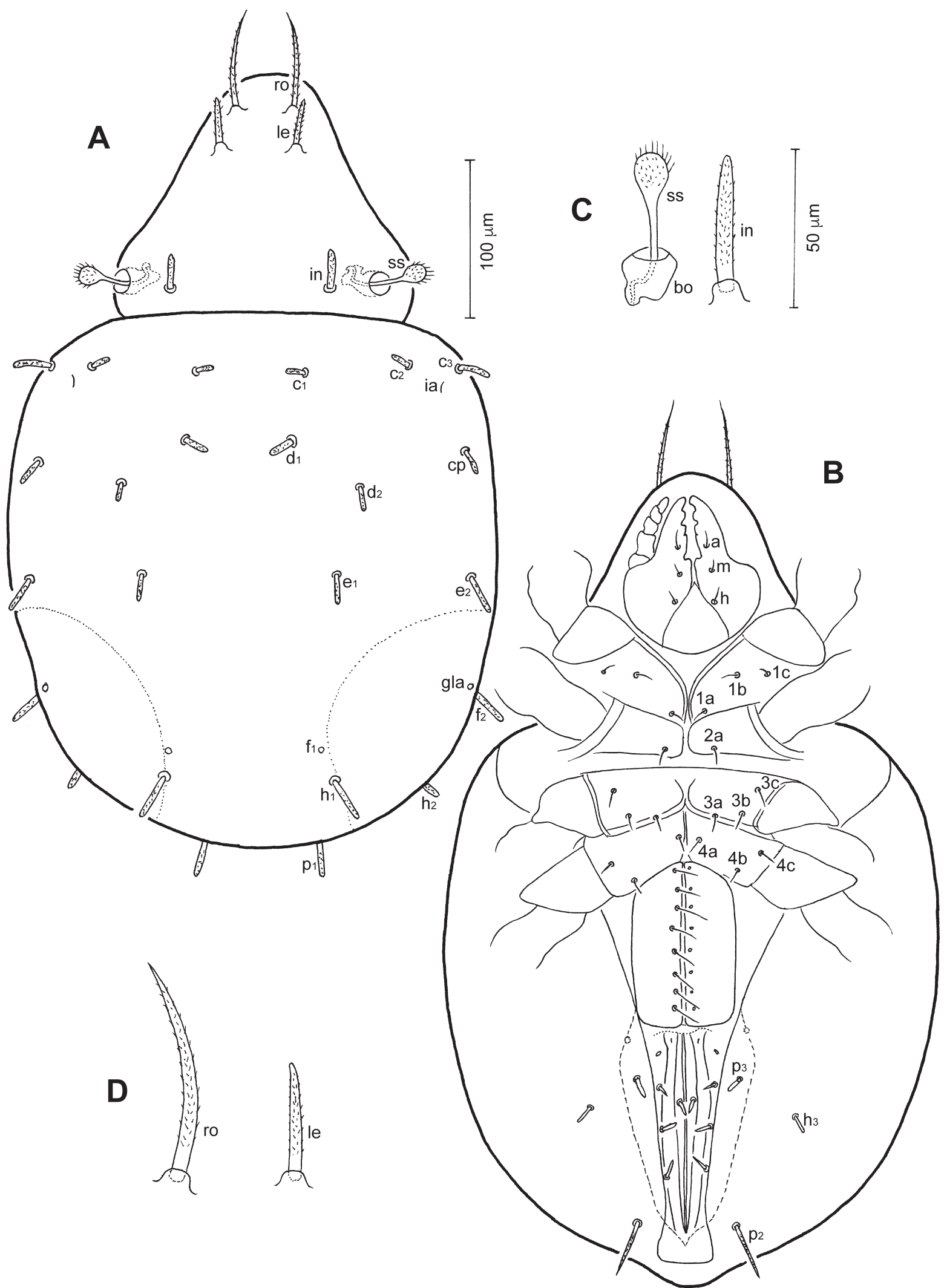

Fig. 3. Trhypochthonius nigricans Willmann, 1928. A-dorsal view; B - ventral view; C-bothrium, sensillus and interlamellar seta; D — rostral and lamellar seta. A, B and C, D to the same scale, respectively. 
Family Thyrisomidae Grandjean, 1954

Genus Banksinoma Oudemans, 1930

Type species: Notaspis lanceolata Michael, 1885

\section{Banksinoma exobothridialis Bayartogtokh, 1997}

(Fig. 4)

Measurements. Adult body length: $384 \mu \mathrm{m}$, width of notogaster: $250 \mu \mathrm{m}$, length of notogaster: $256 \mu \mathrm{m}$.

Supplementary description. Body colour yellowish-brown. Integument with thin granular cerotegument, distinctly tuberculated on exobothridial region, lateral part of prodorsum and notogaster. Rostrum triangular, its tip pointed. Rostral seta thin, finely barbed, inserted dorsally close together, $72 \mu \mathrm{m}$ long. Lamellar costulae short, but rather wide, slightly widened anteriorly; translamellar region bearing a number of conical tubercles. Lamellar seta slightly thicker than ro, finely barbed, $101 \mu \mathrm{m}$ long. Interlamellar seta with fine barbs, $70 \mu \mathrm{m}$ long. Exobothridial seta barbed, $35 \mu \mathrm{m}$ long. Bothridium irregular cup shaped, directed anterolaterad; sensillus with distally pointed fusiform head, $71 \mu \mathrm{m}$ long (Fig. 4A, C). Notogaster almost rounded; ten pairs of notogastral setae; $c$ relatively thicker, but shorter than other setae, $29 \mu \mathrm{m}$ long; setae $p_{2}$ and $p_{3} 32-35 \mu \mathrm{m}$ long; other setae $45-58 \mu \mathrm{m}$ long. Lyrifissure $i m$ and opistosomal gland opening well developed (Fig. 4A). Hypostomal setae thin, smooth; setae $a$ relatively shorter than moderately long $m$ and $h$. Epimeral setae smooth, setal formula: 3-1-3-3. Anal and genital apertures large, situated close to each other; six pairs of genital, one pair of aggenital, two pairs of anal and three pairs of adanal setae thin, smooth; adanal lyrifissure obliquely located close to anterolateral margin of anal aperture (Fig. 4B); legs monodactylous.

Material examined. Six specimens: SedgeSphagnum bog, $10 \mathrm{~km}$ southwest of the city of Tomsk, Tomsk Region, Russia $\left(56^{\circ} 26^{\prime} 30^{\prime \prime} \mathrm{N}, 84^{\circ}\right.$ 50'06"E), 1 October 2015, Leg. M.L. Egorova.

Remarks. The characters of the present material correspond well with those of the Asian materials studied by Bayartogtokh (1997, 2006), Akrami and Behmanesh (2014).

\section{Banksinoma longisetosa Bayartogtokh and Aoki, 1998}

(Fig. 5)

Measurements. Adult body length: $400 \mu \mathrm{m}$, width of notogaster: $259 \mu \mathrm{m}$, length of notogaster: $275 \mu \mathrm{m}$.
Supplementary description. Body colour yellowish-brown. Integument with thin granular cerotegument, distinctly tuberculated on exobothridial region. Rostrum triangular, not pointed, but rounded. Rostral seta thin, smooth, inserted dorsally, $60 \mu \mathrm{m}$ long. Lamellar costulae short, but rather wide at base, narrowed anteriorly; translamella absent. Lamellar seta thin, finely barbed, $88 \mu \mathrm{m}$ long. Interlamellar seta with fine barbs, $92 \mu \mathrm{m}$ long. Exobothridial seta smooth, $36 \mu \mathrm{m}$ long. Bothridium irregular cup shaped, directed anterolaterad; sensillus narrow fusiform, tapered distally, $80 \mu \mathrm{m}$ long (Fig. 5A, D). Notogaster slightly oval; ten pairs of notogastral setae; $c$ relatively thicker, but shorter than other setae, $18 \mu \mathrm{m}$ long; setae $p_{1} 32 \mu \mathrm{m}, p_{2}$ and $p_{3} 19-21 \mu \mathrm{m}$ long; other setae 40-48 $\mu \mathrm{m}$ long. Lyrifissure $i m$ and opistosomal gland opening well developed (Fig. 5A). Hypostomal setae thin, smooth; setae $a$ relatively shorter than moderately long $m$ and $h$. Epimeral setae smooth, setal formula: 3-1-3-3. Anal and genital apertures large, situated close to each other; six pairs of genital, one pair of aggenital, two pairs of anal and three pairs of adanal setae thin, smooth; adanal lyrifissure obliquely located close to anterolateral margin of anal aperture (Fig. 5B, C); legs monodactylous.

Material examined. Thirteen specimens: SedgeSphagnum bog, $10 \mathrm{~km}$ southwest of the city of Tomsk, Tomsk Region, Russia $\left(56^{\circ} 26^{\prime} 30^{\prime \prime} \mathrm{N}\right.$, $84^{\circ} 50^{\prime} 06^{\prime \prime}$ E), 1 October 2015, Leg. M.L. Egorova.

Remarks. The characters of the present material correspond well with those of the materials studied by Bayartogtokh and Aoki (1998).

\section{Family Suctobelbidae Jacot, 1938 \\ Genus Suctobelbella Jacot, 1937 \\ Type species: Suctobelbella serratirostrum Jacot, 1937}

\section{Suctobelbella palustris (Forsslund, 1951)}

(Fig. 6)

Measurements. Adult body length: $259 \mu \mathrm{m}$, width of notogaster: $150 \mu \mathrm{m}$, length of notogaster: $163 \mu \mathrm{m}$.

Supplementary description. Body colour light brown. Integument smooth, only regions near to tectopedial fields with tubercles. Rostrum with two small teeth and rectangular indentation between them (Fig. 6E). Tectopedial field large, elongate oval; knob-like tubercle pentagonal. Rostral seta geniculate, ciliate unilaterally in medial part, $31 \mu \mathrm{m}$ long. Lamellar seta setiform, smooth, $16 \mu \mathrm{m}$ long. Interlamellar seta thin, $4 \mu \mathrm{m}$ long (Fig. 6A). Sensil- 


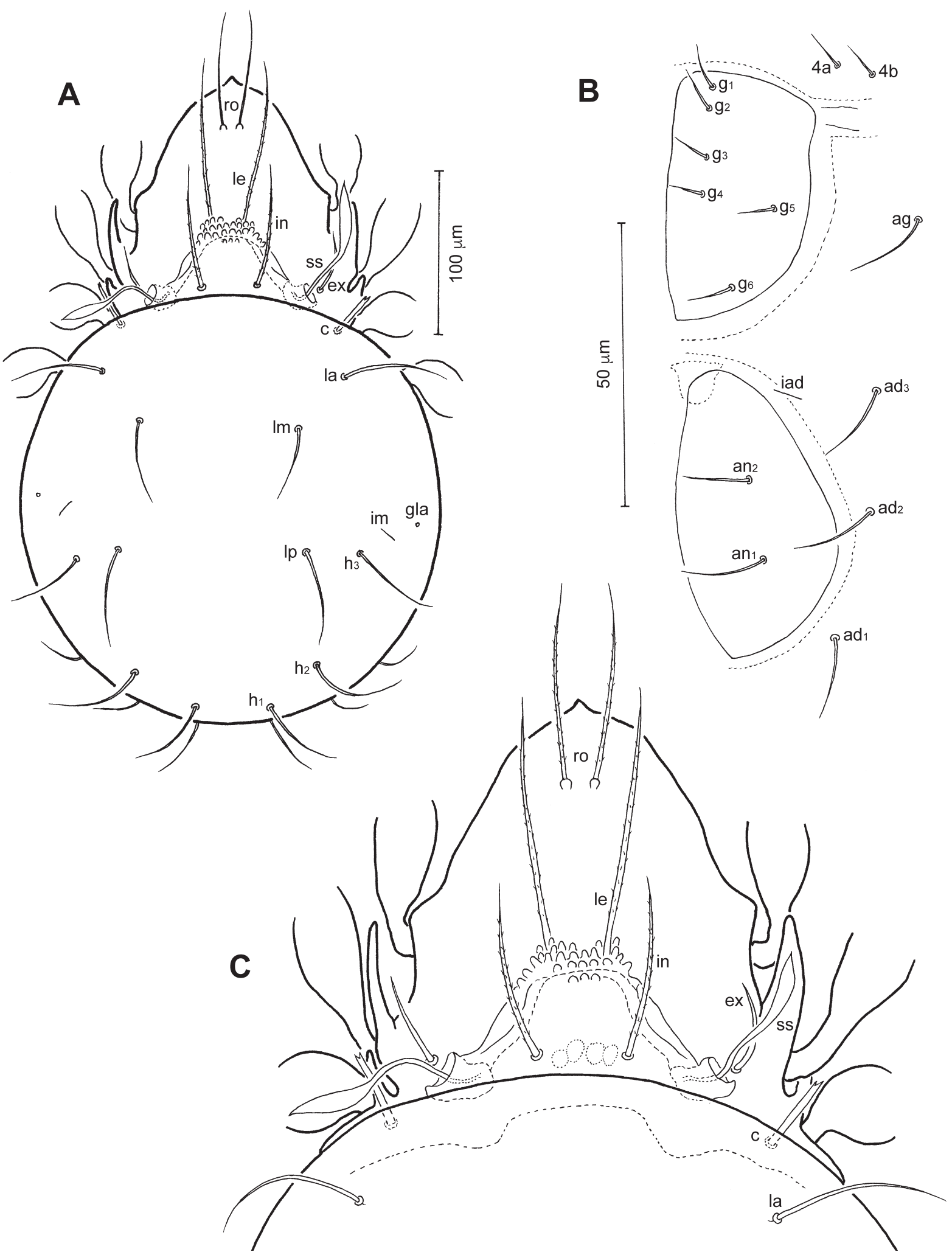

Fig. 4. Banksinoma exobothridialis Bayartogtokh, 1997. A-dorsal view; B-anogenital region; C-prodorsum. B, C to the same scale.

lus clavate, with long stalk and oval, smooth head narrowed distally (Fig. 6C). One pair of interbothridial and another pair of postbothridial tubercles present (Fig. 6D). Notogaster almost rounded, two pairs of humeral tubercles well developed, lateral tubercle larger than median tubercle. Nine pairs of notogastral setae thin, smooth, $p_{1}, p_{2} 12-15 \mu \mathrm{m}$, other setae $26-28 \mu \mathrm{m}$ long. Lyrifissure $i m$ and opis- 
M.L. Egorova et al.

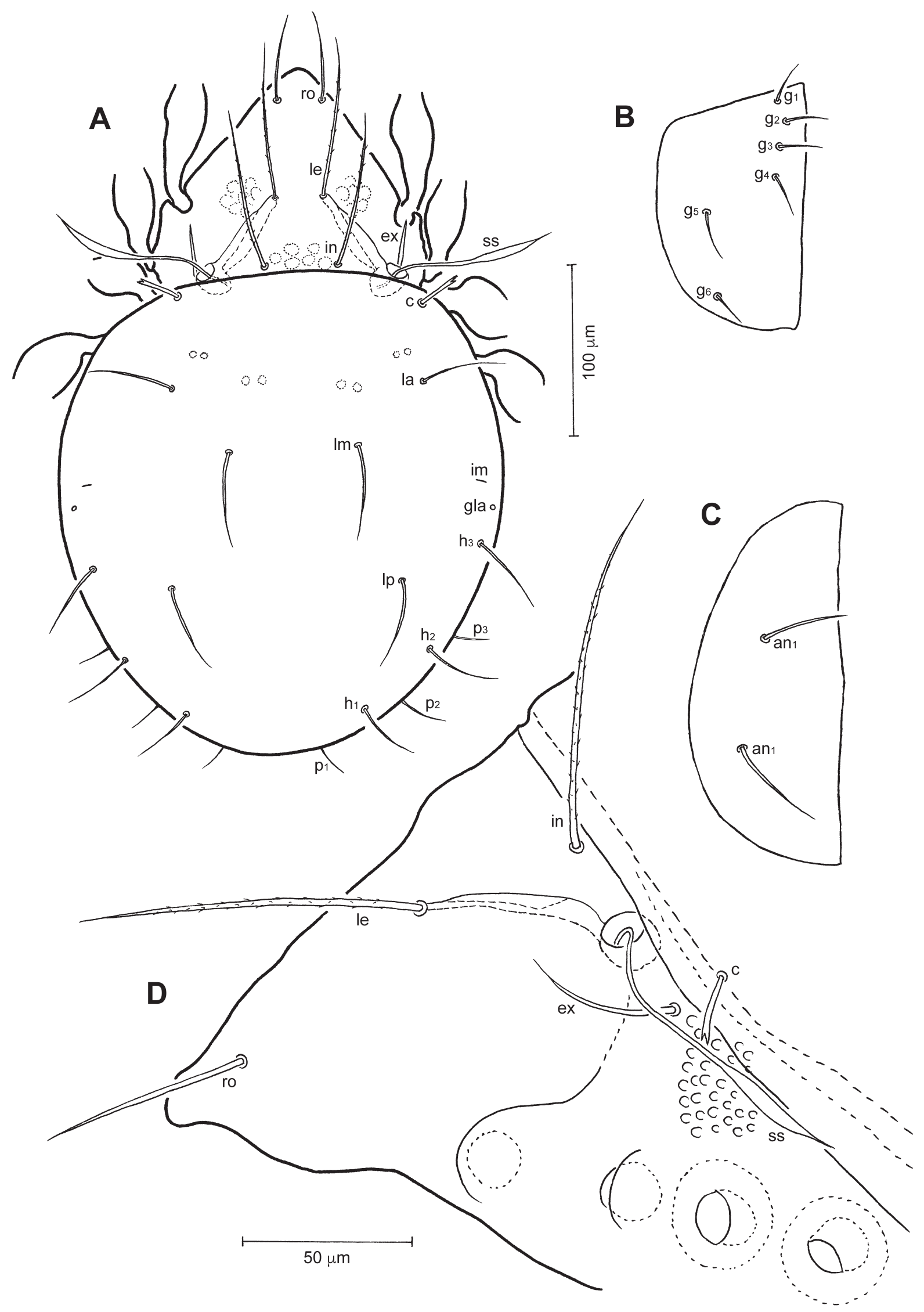

Fig. 5. Banksinoma longisetosa Bayartogtokh and Aoki, 1998. A—dorsal view; B — genital plate; C—anal plate; D— dorso-lateral view of prodorsum. B, C, D to the same scale. 


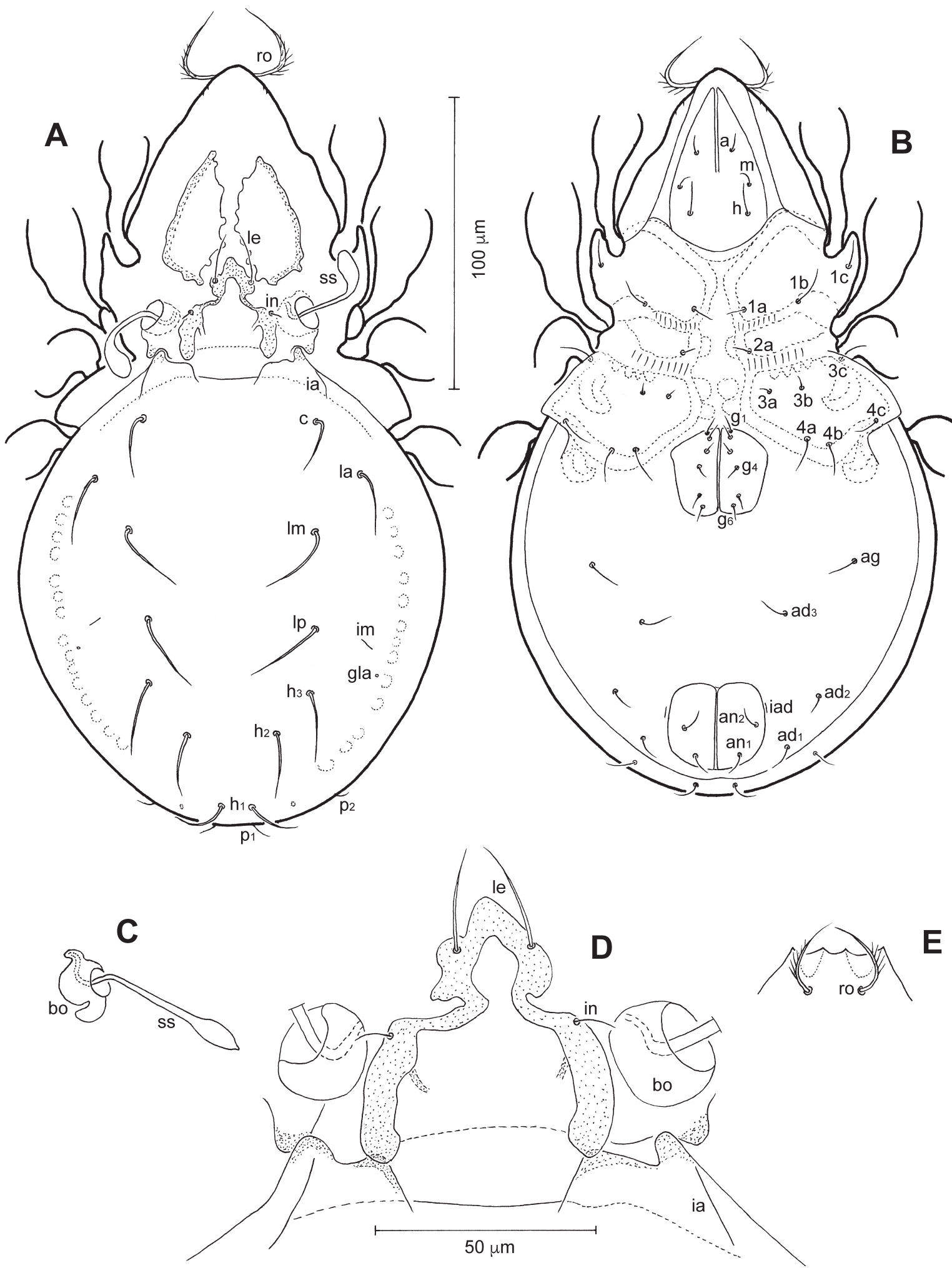

Fig. 6. Suctobelbella palustris (Forsslund, 1951). A-dorsal view; B-ventral view; C-bothridium and sensillus; D-interbothridial region, E-dorso-frontal view of rostrum. A, B and C, D, E to the same scale, respectively.

thonotal gland opening clearly developed (Fig. 6A). Subcapitulum longer than wide, subcapitular setae setiform, smooth; seta $h 14 \mu \mathrm{m}, a$ and m 6-9 $\mu \mathrm{m}$ long. Epimeral setae setiform, smooth, setal for- mula 3-1-3-3. Six pairs of genital, one pair of aggenital, two pairs of anal and three pairs of adanal setae thin, smooth. Lyrifissures iad located in paraanal position (Fig. 6B); legs monodactylous. 


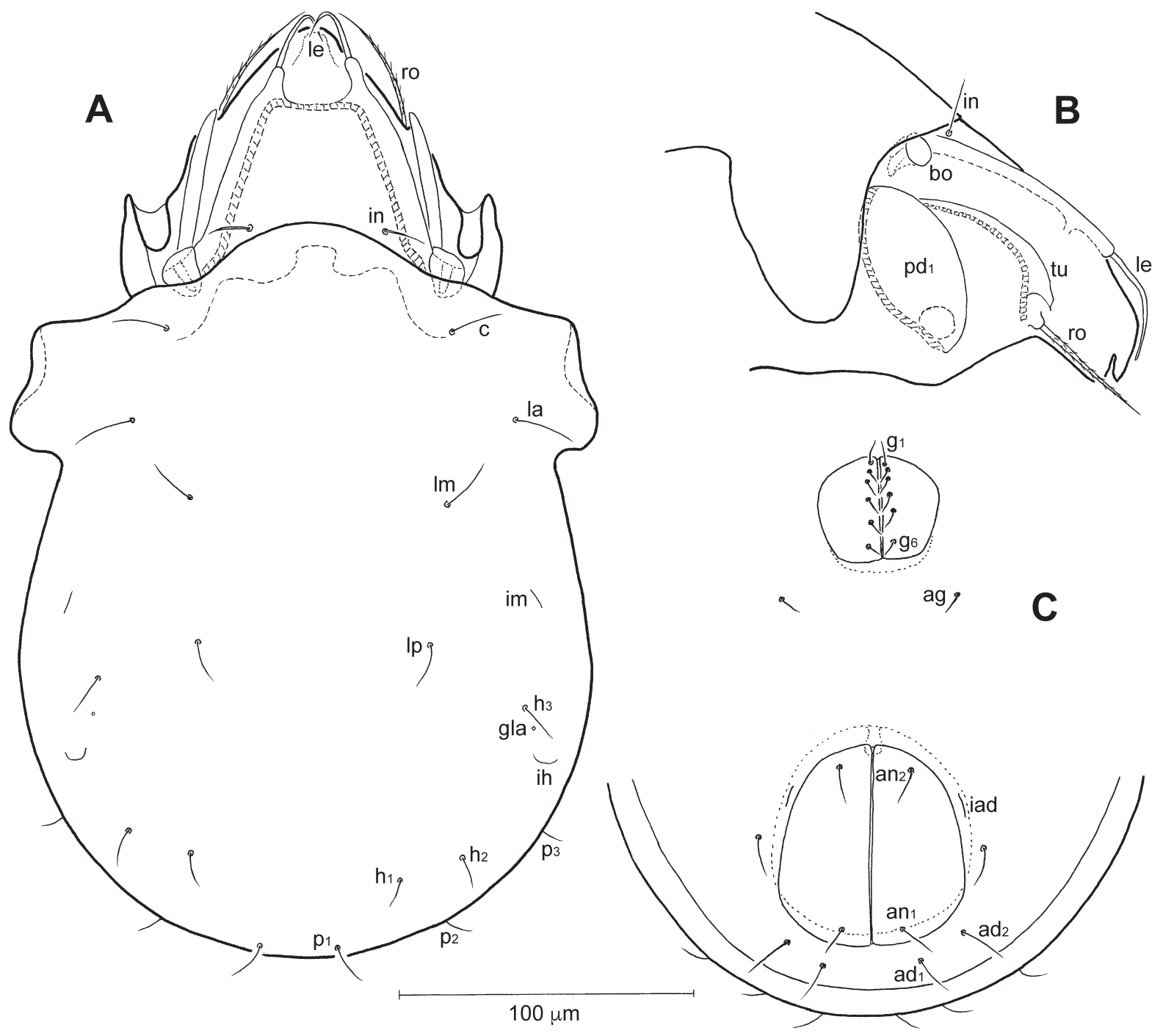

Fig. 7. Limnozetes ciliatus (Schrank, 1803). A-dorsal view; B-lateral view of prodorsum, C-anogenital region.

Material examined. Nineteen specimens: SedgeSphagnum bog, $10 \mathrm{~km}$ southwest of the city of Tomsk, Tomsk Region, Russia (56 $26^{\prime} 30^{\prime \prime} \mathrm{N}$, $\left.84^{\circ} 50^{\prime} 06^{\prime \prime} \mathrm{E}\right), 1$ October 2015, Leg. M.L. Egorova.

Remarks. The characters of the present material correspond well with those of the materials studied by Strenzke (1951), Forsslund (1953), Mahunka (1996).

\section{Family Limnozetidae Thor, 1937 \\ Genus Limnozetes Hull, 1916}

Type species: Acarus ciliatus Schrank, 1803

\section{Limnozetes ciliatus (Schrank, 1803)}

(Fig. 7)

Measurements. Adult body length: 307-323 $\mu \mathrm{m}$, width of notogaster: $179-198 \mu \mathrm{m}$, length of notogaster: $227-240 \mu \mathrm{m}$.
Supplementary description. Body colour deep reddish brown to dark brown. Integument tuberculate on prodorsum, lateral margin of podosoma and proximal region of pteromorph; cerotegument finely punctate. Rostrum rounded medially, with pair of lateral indentations; seta ro barbed, $48 \mu \mathrm{m}$ long, curved anteromediad. Lamella slightly narrowed apically; lamellar cusp narrow; seta $l e$, $45 \mu \mathrm{m}$ long, smooth, strongly curved downwards. Translamella present, though sometime interrupted. Seta in thin, smooth, $20 \mu \mathrm{m}$ long. Sensillus not developed; bothridium irregular cup-shaped, partly concealed under anterior margin of notogaster (Fig. 7A, B). Anterior and porterior margins of notogaster rounded; pteromorph subtriangular, distal margin strongly curved ventrally. Notogastral setae thin, smooth, 20-28 $\mu \mathrm{m}$ in length. Epimeral setae all thin, smooth, setal formula 3-1-2-2. Six pairs of genital, one pair 
of aggenital, two pairs of anal and three pairs of adanal setae thin, smooth. Lyrifissures iad located in paraanal position (Fig. 7C); legs monodactylous.

Material examined. Sixty-one adults (females): Sedge-Sphagnum bog, $10 \mathrm{~km}$ southwest of the city of Tomsk, Tomsk Region, Russia $\left(56^{\circ} 26^{\prime} 30^{\prime \prime} \mathrm{N}\right.$, $\left.84^{\circ} 50^{\prime} 06^{\prime \prime} \mathrm{E}\right), 1$ October 2015, Leg. M.L. Egorova.

Remarks. The characters of the present material correspond well with those studied by Hammer (1952), Pérez-Iñigo (1970), Weigmann (2006), Kuriki (2008), Seniczak and Seniczak (2009).

\section{DISCUSSION}

Although oribatid mites have had an association with freshwater habitats at least since the early Jurassic (Labandeira et al. 1997), only a few members of the oribatid lineages Desmonomata and Brachypylina made the transition from terrestrial to freshwater habitats. Yet, there is scant evidence for specific adaptations to aquatic living in these cohorts (Behan-Pelletier and Eamer 2007).

Our work examines recent finds of oribatid mites from a Sphagnum bog in Western Siberia in their taxonomic, biogeographical and ecological contexts. The first species studied by us, Mainothrus badius, is known from the Palaearctic and Nearctic regions. In particular, it has been reported previously from Europe and North America (Marshall et al. 1987; Mahunka and Mahunka-Papp 1995; Weigmann 1997; Seniczak et al. 1998). As for Russia, this species has been found in its European part: more specifically, in Karelia and Smolensk, Moscow and Nizhny Novgorod Regions (Ermilov and Chistyakov 2007). Therefore, our finding represents the first record of M. badius in Asia, with Western Siberia being the easternmost point of its distribution.

In North America, M. badius has been recovered from wet meadows with mosses and scattered low willow shrubs, as well as from Sphagnum mosses associated with an acid bog (Hammer 1952; Seniczak et al. 1998). In Europe, this species was reported from wet bogs, where it mainly occurred in moss cushions (Willmann 1931; Hammen 1959; Weigmann 1997). This species was also recorded, albeit with lesser frequency, in the Sphagnum mat of a dystrophic pond in Poland (Seniczak 2011). In European Russia, abundant occurrence of $M . b a$ dius was recorded in a Sphagnum bog surrounded by mixed forest, composed of Scots pine (Pinus silvestris), silver birch (Betula pendula) and willows (Salix sp.). The above area was dominated by mosses of the genus Sphagnum, and other plants such as Drosera rotundifolia, Oxycoccus microcarpus, Scheuchzeria palustris (Ermilov and Chistyakov 2007). In addition, M. badius was rather abundant in the Sphagnum bogs of the East European Plain (Minor et al. 2016).

The second species examined by us-Trhypochthonius nigricans - is rather rare. It was originally described from moss near a lake in Germany (Willmann 1928). Later, this species was recovered from a few places in Germany, Poland and European Russia (Karelia; Moscow and Pskov Regions), where it occurred predominantly in bogs and moist forest soils (Krivolutsky 1995; Weigmann 1997; Szywilewska-Szczykutowicz and Olszanowski 2007; Weigmann and Raspotnig 2009). In Asia, T. nigricans is known from Central and Eastern Siberia (Golosova et al. 1983), and from the Kushiro Moor in Hokkaido, Northern Japan (Aoki 1995). Thus, we recorded T. nigricans for the first time in Western Siberia.

In North America, T. nigricans was recovered from Sphagnum bogs in New York, USA and New Brunswick, Canada (Seniczak and Norton 1994). According to the above authors, this species is probably common in the cold bogs of southeastern Canada and northeastern US. Additionally, according to Szywilewska-Szczykutowicz and Olszanowski (2007), this species was collected from the following habitats: a pine buttress in the pine-oak uplands of Texas, and grassy litters as well as a log near a pond in Kentucky. According to Seniczak (2011), this species is restricted to floating Sphagnum mats that occur in very wet and oligotrophic conditions. Additionally, its juveniles are most abundant in the summer, while adults are more abundant in the spring (Seniczak 2011). Although Mumladze et al. (2013) considers both M. badius and $T$. nigricans bog-specific, these are known only from a few bogs in the Holarctic region.

The third species studied by us-Banksinoma exobothridialis - is an Eastern Palaearctic species, previously known from Mongolia and Iran (Bayartogtokh 2010; Akrami and Behmanesh 2014). Therefore, ours is a new record of this species in Russia. In Mongolia, it inhabits cool temperate taiga forest litter and the soils of dry steppe, mountain steppe and desert oases (Bayartogtokh 2010; Bayartogtokh and Yondon 2018). In Iran, this species was found in the roadside soil, associated with Phragmites australis and Poaceae grasses (Akrami and Behmanesh 2014). 
Another species of this genus-Banksinoma longisetosa - was known up to now only from Mongolia, where it inhabits birch and larch forest litter, as well as mountain steppe and meadow soils (Bayartogtokh and Aoki 1998; Bayartogtokh 2010). Hence, Banksinoma longisetosa has been recorded for the first time in Russia. The occurrence of both of the above species in a West Siberian bog is surprising, since they were known previously from drier habitats, located much further south (see below).

The fifth species we studied-Suctobelbella palustris - has a Holarctic distribution. Previously, its occurrence has been recorded in Central and Northern Europe (Germany, Hungary and Sweden) and North America (Canada). In Europe, it inhabits wet grass meadows, reed beds, floating and water-soaked Sphagnum, as well as floodplains of forest lakes (Strenzke, 1951; Forsslund 1953; Mahunka 1996). In North America, this species occurs in luxuriant moss and Carex, which grow in moist meadows, surrounded by Betula, Salix and other trees (Hammer 1952). This species was assigned to the bog-specific species group, which is rather commonly distributed in the peat bogs of the Holarctic region (Mumladze et al. 2013).

The last species examined by us-Limnozetes ciliatus - is a Holarctic taxon, widely distributed in both Nearctic and Palaearctic regions. This is a truly aquatic species, typically inhabiting wet Sphagnum bogs, fens and the edges of forest lakes, covered with Sphagnum and other mosses (Willmann 1931; Sellnick 1960; Weigmann 2006; Weigmann and Deichsel 2006; Kuriki 2008; Seniczak and Seniczak 2009). According to Mumladze et al. (2013), this is one of the most widespread bog-specific species of the Holarctic region. Minor et al. (2016) found that L. ciliatus prefers the Sphagnum microhabitat: in particular, S. cuspidatum, associated with higher groundwater levels. This is one of a few oribatid species dominating Sphagnum mats in a dystrophic pond in Poland throughout all seasons (Seniczak 2011).

Thus, the four species (M. badius, T. nigricans, S. palustris and L. ciliatus) we found in a Sphagnum bog of West Siberia are known to be typical inhabitants of semiaquatic environments, such as bogs, wet meadows, fens, and the edges of lotic habitats. However, the occurrence of two Banksinoma species in a high-latitude bog is surprising, since they previously have been recorded only in dry habitats, located in low southern latitudes: more specifically, in the soils of mountain and plain steppe and in the litter of deciduous and coniferous forests. Schatz and Behan-Pelletier (2008) state that many terrestrial oribatid species can be found in aquatic habitats as chance stragglers from the surrounding habitats. Also, after being transported by periodic or unpredictable floods, oribatid mites can survive for long periods of time by associating with drier microhabitats. Although this may be true for our species, further studies of soil mite fauna colonization of bogs after the last glaciation are necessary to answer this question. Additionally, we know that many species of oribatid mites are generalist feeders and some do not exhibit habitat specialization (Aoki 1967; Behan-Pelletier and Eamer 2007). Both of the above Banksinoma species might be such eurybiontic taxa, occurring in different habitat types. According to Druk and Vilkamaa (1988) and Minor et al. (2016), in drier bog microhabitats, hygrophilic species are replaced by tyrphophilic litter- and soil-dwellers. In such habitats, smaller deep-soil taxa appear, and eurybionts increase in abundance.

\section{ACKNOWLEDGMENTS}

We are grateful to the anonymous reviewer for critical reading of the manuscript with valuable comments, and Dr. A. V. Tolstikov for his kind assistance in reviewing this work. This research was supported by JSPS KAKENHI P19170, and the additional support by the National University of Mongolia is highly appreciated.

\section{REFERENCES}

Akrami, M.A. and Behmanesh, M. 2014. [First report of Banksinoma exobothridialis (Acari: Oribatida: Thyrisomidae) from Iran]. Journal of the Entomological Society of Iran, 34(2): 29-30. (In Persian)

Aoki, J. 1967. Microhabitats of oribatid mites on a forest floor. Bulletin of the National Science Museum, 10: 133-138.

Aoki, J. 1995. [Faunal and ecological study on the oribatid mites of Kushiro Moor. 1]. Bulletin of the Institute of Environmental Science and Technology Yokohama National University, 21: 187-194. (In Japanese)

Bayartogtokh, B. 1997. [New species of oribatid mites (Acari: Oribatida) from Mongolia]. Zoologicheskii Zhurnal, 76(1): 118-121. (In Russian)

Bayartogtokh, B. 2006. Two species of oribatid mites of the genus Banksinoma (Acari: Oribatida: Banksinomidae) from Mongolia. Acarina, 14(2): 175-179.

Bayartogtokh B. 2010. [Oribatid Mites of Mongolia (Acari: Oribatida)]. KMK Scientific Press, Moscow, 371 pp. (In Russian)

Bayartogtokh, B. and Aoki, J. 1998, New and little known oribatid mites from Mongolia. Bulletin of 
the Institute of Environmental Science and Technology Yokohama National University, 24: 121-135.

Bayartogtokh, B. and Yondon, G. 2018. [Fauna and populations of oribatid mites in the Trans-Altai Gobi. Problems of Soil Zoology]. In: A.V. Uvarov (Ed.). Materials of the XVIII All-Russian Conference of Soil Zoology. KMK Scientific Press, Moscow, pp. 28-29. (In Russian)

Behan-Pelletier, V.M. and Eamer, B. 2007. Aquatic Oribatida: adaptations, constraints, distribution and ecology. In: J.B. Morales-Malacara, V. BehanPelletier, E. Ueckermann, T.M. Pérez, E. G. Estrada-Venegas and M. Badil (Eds.). Acarology XI: Proceedings of the International Congress. Instituto de Biología and Facultad de Ciencias, Universidad Nacional Autónoma de México; Sociedad Latinoamericana de Acarología, México, pp. 71-82.

Behan-Pelletier, V.M. and Norton, R. A. 2016. Sarcoptiformes: Oribatida. In: J.H. Thorp and D.C. Rogers (Eds.). Thorp and Covich's Freshwater Invertebrates (4th ed.), Vol. II: Keys to Nearctic Fauna. Elsevier, Boston, pp. 295-305.

Druk, A. Ya. and Vilkamaa, P. 1988. [Microarthropods of raised bogs of the northern European part of the USSR]. In: D. A. Krivolutsky (Ed.). [Soil biology of Northern Europe]. Nauka, Moscow, pp. 190198. (In Russian)

Ermilov, S. G. and Chistyakov, M.P. 2007. [Mainothrus badius as a little known species of oribatid mites (Acari, Oribatida) and its geographic distribution in Russia]. Povolzhsky Ekologichesky Zhurnal, 4: 345-347. (In Russian)

Forsslund, K. 1953. Schwedische Oribatei (Acari). II. Entomologisk Tidskrift, 74(3): 152-157.

Golosova, L., Karppinen, E. and Krivolutsky, D.A. 1983. List of oribatid mites (Acarina, Oribatei) of northern Palaearctic region. II. Siberia and the Far East. Acta Entomologica Fennica, 43: 1-14.

Grandjean, F. 1932. Observations sur les Oribates (3 série). Bulletin du Muséum National d'Histoire Naturelle, 4(3): 292-306.

Grandjean, F. 1964. La soleìnidiotaxie des Oribates. Acarologia, 6: 529-556.

Hammen, L. van der 1959. Berlese's primitive oribatid mites. Zoologische Verhandelingen, 40: 1-93.

Hammer, M. 1952. Investigations on the microfauna of Northern Canada, Part I. Oribatidae. Acta Arctica, 4: 1-108.

Kremenetski, K.V., Velichko, A.A., Borisova, O.K., MacDonald, G.M., Smith, L.C., Frey, K.E. and Orlova, L.A. 2003. Peatlands of the Western Siberian lowlands: current knowledge on zonation, carbon content and Late Quaternary history. Quaternary Science Reviews, 22: 703-723.
Krivolutsky, D.A. 1995. [Oribatid Mites: Morphology, Development, Phylogeny, Ecology, Methods of Study and Characteristics of the Model Species Nothrus palustris]. Nauka Publishers, Moscow, 224 pp. (In Russian)

Kuriki, G. 2008. The life cycle of Limnozetes ciliatus (Schrank, 1803) (Acari: Oribatida). Journal of the Acarological Society of Japan, 17(2): 75-85.

Labandeira, C.C., Philips, T.L. and Norton, R. A. 1997. Oribatid mites and the decomposition of plant tissues in Paleozoic coal swamp forests. Palaios, 12: 319-353.

Liss, O.L., Abramova, L.I., Avetov, N.A., Berezina, N.A., Inisheva, L.I., Kurnishkova, T.V., Sluka, Z.A., Tolpysheva, T.Yu. and Shvedchikova, N.K. 2001. [Bog Systems of Western Siberia and Their Importance in Nature Conservation]. Grif and $\mathrm{K}^{\circ}$, Moscow-Tula, 584 pp. (In Russian)

Mahunka, S. 1996. Oribatids of the Bükk National Park (Acari: Oribatida). In: S. Mahunka (Ed.). The Fauna of the Bükk National Park. Natural History Museum Press, Budapest, pp. 491-532.

Mahunka, S. and Mahunka-Papp, L. 1995. The Oribatid Species Described by Berlese (Acari). Hungarian Natural History Museum, Budapest, 325 pp.

Marshall, V.G., Reeves, R.M. and Norton, R.A. 1987. Catalogue of the Oribatida (Acari) of Continental United States and Canada. Memoirs of the Entomological Society of Canada, 139: 3-418.

Mikheeva, V.L. 2008. [Succession of oribatid mites (Oribatei) in upper bog of the Nizhnevartov Dirstrict]. Vestnik Tomskogo Gosudarstvennogo Universiteta, 317: 246-248. (In Russian)

Minor, M.A., Ermilov, S.G., Philippov, D.A. and Prokin, A.A. 2016. Relative importance of local habitat complexity and regional factors for assemblages of oribatid mites (Acari: Oribatida) in Sphagnum peat bogs. Experimental and Applied Acarology, 70: 275-286. DOI: 10.1007/s10493-016-0075-9

Mumladze, L., Murvanidze, M. and Behan-Pelletier, V. 2013. Compositional patterns in Holarctic peat bog inhabiting oribatid mite (Acari: Oribatida) communities. Pedobiologia, 56: 41-48. DOI: 10.1016/j. pedobi.2012.10.001

Norton, R.A. 1977. A review of F. Grandjean's system of leg chaetotaxy in the Oribatei (Acari) and its application to the family Damaeidae. In: D.L. Dindal (Ed.): Biology of Oribatid Mites. SUNY College of Environmental Science and Forestry, Syracuse, pp. 33-61.

Norton, R.A. and Behan-Pelletier, V.M. 2009. Chapter 15, Oribatida. In: G.W. Krantz and D.E. Walter (Eds.). A Manual of Acarology. Texas Tech. University Press, Lubbock, pp. 421-564. 
Pérez-Iñigo, C. 1970. Acaros Oribátidos de suelos de España Peninsular e Islas Baleares (Acari, Oribatei). Parte II. Revista Española de Entomología, 45: 241-317.

Schatz, H. and Behan-Pelletier, V.M. 2008. Global diversity of oribatids (Oribatida; Acari, Arachnida). Hydrobiologia, 595: 323-328.

Sellnick, M. 1960. Formenkreis: Hornmilben, Oribatei. Nachtrag. In: P. Brohmer, P. Ehrmann and G. Ulmer (Eds.). Die Tierwelt Mitteleuropas, Leipzig, 3(4): 45-134.

Seniczak, A. 2011. Oribatid mites (Acari, Oribatida) and their seasonal dynamics in a floating bog mat in Jeziorka Kozie Reserve, Tuchola Forest (Poland). Biological Letters, 48: 3-11. DOI: 10.2478/ v10120-011-0001-0

Seniczak, S. and Norton, R. A. 1994. The morphology of juvenile stages of moss mites of the family Trhypochthoniidae (Acari: Oribatida). II. Zoologischer Anzeiger, 233: 29-44.

Seniczak, S., Norton, R. A. and Wang, H-F. 1998. The morphology of juvenile stages of moss mites of the family Trhypochthoniidae (Acari: Oribatida), and the taxonomic status of some genera and species. Zoologischer Anzeiger, 237: 85-95.

Seniczak, S. and Seniczak, A. 2009. Morphology of some species of Limnozetes Hull, 1916 (Acari: Oribatida: Limnozetidae), and keys to the larvae and nymphs. Annales Zoologici, 59(3): 387-396.

Strenzke, K. 1951. Die norddeutschen Arten der Oribatiden-Gattung Sucfobelba. Zoologischer Anzeiger, 147: 147-166.

Szywilewska-Szczykutowicz, A. and Olszanowski, Z. 2007. Redescription of C. Willmann's Holarctic species of the genus Trhypochthonius (Acari: Oribatida: Trhypochthoniidae). Zootaxa, 1406: 17-24.

Tolstikov, A.V. 1998. [Oribatid mites (Acariformes, Oribatei) in the West Siberian south fresh-water lake periphyton communities]. In: [Invertebrate animals of the South Urals and Adjacent Territories. Materials of the All-Russian Conference]. Kurgan, pp. 314-316. (In Russian)

Tolstikov, A. V. and Petrova-Nikitina,A.D. 2008. [Mites of the order Acariformes A. Zachv. in water: diversity of habitats]. In: S.N. Gashev (Ed.). [Ecology of Animals and Faunistics]. Tyumen State University Press, Tyumen, pp. 109-137. (In Russian)

Weigmann, G. 1997. New and old species of Malaconothroidea from Europe (Acari, Oribatida). Spixiana, 20: 199-218.

Weigmann, G. 2006. Hornmilben (Oribatida). Die Tierwelt Deutschlands, 76. Goecke and Evers, Teil. Keltern. 520 pp.

Weigmann, G. and Deichsel, R. 2006. Acari: Limnic Oribatida. In: R. Gerecke (Ed.). Chelicerata: Araneae, Acari I. Süßwasserfauna von Mitteleuropa, Vol. 7/2-1. Spektrum, München, pp. 89-112.

Weigmann, G. and Raspotnig, G. 2009. Comparative morphological and biometrical studies on Trhypochthonius species of the tectorum species group (Acari: Oribatida: Trhypochthoniidae). Zootaxa, 2269: 1-31.

Willmann, C. 1928. Neue Oribatiden I. Zoologischer Anzeiger, 76: 1-5.

Willmann, C. 1931. Moosmilben oder Oribatiden (Cryptostigmata). In: F. Dahl (Ed.). Die Tierwelt Deutschlands. Bd. 22, Vol. 5. Gustav Fischer, Jena, pp. 79-200. 